\title{
Are Minority Women Able To Use Their Degree From American Public University System To Further Their Career?
}

\author{
Ana Machuca, Kaplan University, USA \\ Enid Naranjo, American Public University System, USA \\ Leticia Apolinaris, Kaplan University, USA \\ Carrie Teresa Maison, Northern Virginia Community College, USA
}

\begin{abstract}
The authors examined whether minority women alumni from an online degree program at American Public University System (APUS) were able to use their degree to further their careers. Alumni minority women were surveyed to determine if the education they obtained prepared them for their current job, opened new doors for job opportunities, opened doors for promotions, and/or enhanced their ability for a specific career field. It is important to understand the unique needs of minority women students in an online study environment.
\end{abstract}

Keywords: Minority Women; Education; Career Field

\section{INTRODUCTION}

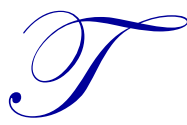

he objective of this study was to investigate whether female minorities enrolled in an online degree program at America Public University Systems (APUS) were able to benefit from their education and excel in their careers. Arbona stated, "Educational attainment constitutes the bedrock of career development and choice" (Offet-Gartner, 2008). As the population of minority women with degrees continues to grow in the United States, it is important to determine if obtaining a degree is actually benefiting their careers. According to the U.S. Department of Education's National Center for Educational Statistics (NCES) report titled The Condition of Education 2011, from 1998 to 2009 the percentage of degrees earned by females varied substantially. The number of Associate's degrees fluctuated between $61 \%$ and $62 \%$, remained steady around $57 \%$ for Bachelor's degrees, and the percentage of Master's increased from 58\% to 60\%. In nearly all levels of degrees within different racial/ethnic groups, women earned the majority of degrees in 2008-09. African-American females earned $68 \%$ of Associate's degrees, 66\% of Bachelor's degrees, $72 \%$ of Master's degrees, and $62 \%$ of firstprofessional degrees. Hispanic females earned $62 \%$ of Associate's degrees, $61 \%$ of Bachelor's degrees, $64 \%$ of Master's degrees, and 53\% of first-professional degrees. This study of minority women alumni was conducted in order to shed light on those women whose careers have changed and/or improved as a result of earning their degree.

\section{METHOD}

American Public University System (APUS) consulted alumni one year after graduation who held an Associate's, Bachelor's, or Master's degree in a routine survey. The survey contained several questions, some of which were used in this study, such as: 1) Has your degree prepared you for your current job?, 2) Has your degree opened doors for new job opportunities?, 3) Has your degree opened doors for any promotions?, and 4) Has your degree enhanced your ability for a specific career field?

The surveys were collected and maintained by APUS, the data were compiled and consisted solely of input from minority women, and the results were provided to the authors in an Excel worksheet and contained only the deidentified data set; no identifying information was provided. The survey population consisted of four students who graduated with an Associate's degree, 41 with a Bachelor's Degree, and 30 with a Master's Degree, for a total of 75 alumni. The race/ethnicity of these alumni was four American Indian or Alaskan, seven Asian, 40 African 
American, 22 native Hispanic or Latino, and two native Hawaiian or Other Pacific Islander. The degrees for the alumni in this study were conferred in 2010 with the survey responses collected in 2011 (see Table 1). The responses came from diverse programs with the largest concentration of alumni in the areas of Business Administration, Criminal Justice, and Management, respectively.

Table 1: Race/Ethnicity of Alumni

\begin{tabular}{|c|c|c|c|}
\hline \multicolumn{2}{|r|}{ Race/Ethnicity } & \multicolumn{2}{|c|}{ Alumni in Category } \\
\hline 1 & American Indian or Alaskan Native & 4 & $5 \%$ \\
\hline 2 & Asian & 7 & $9 \%$ \\
\hline 3 & Black or African American, Non-Hispanic & 40 & $53 \%$ \\
\hline 4 & Hispanic or Latino & 22 & $29 \%$ \\
\hline 5 & Native Hawaiian or Other Pacific Islander & 2 & $3 \%$ \\
\hline & Total & 75 & $100 \%$ \\
\hline
\end{tabular}

\section{RESULTS}

Under question number 1, "Has your degree prepared you for your current job?", 20\% of the alumni strongly agreed, $40 \%$ agreed, $27 \%$ neither agreed nor disagreed, $8 \%$ disagreed, and 5\% strongly disagreed. Under question number 2, "Has your degree opened doors for new job opportunities?", 25\% strongly agreed, 37\% agreed, $27 \%$ neither agreed nor disagreed, $7 \%$ disagreed, and $4 \%$ strongly disagreed. Under question number 3, "Has your degree opened doors for any promotions?", $21 \%$ of the alumni strongly agreed, 39\% agreed, 25\% neither agreed nor disagreed, $12 \%$ disagreed and 3\% strongly disagreed. Under question number 4, "Has your degree enhanced your ability for a specific career field?", 37\% of the alumni strongly agreed, $41 \%$ agreed, $16 \%$ neither agreed nor disagreed, $3 \%$ disagreed and 3\% strongly disagreed (see Table 2).

Table 2: Minority Alumni Question Results

\begin{tabular}{|c|c|c|c|c|c|c|}
\hline \multicolumn{7}{|c|}{ 1. Has your degree prepared you for your current job? } \\
\hline & & & Associate's & Bachelor's & Master's & Total \\
\hline \multirow{6}{*}{$\begin{array}{l}5=\text { Strongly Agree } \\
4=\text { Agree } \\
3=\text { Neither } \\
2=\text { Disagree } \\
1=\text { Strongly Disagree } \\
\text { Total }\end{array}$} & 15 & $20 \%$ & 0 & 8 & 7 & 15 \\
\hline & 30 & $40 \%$ & 3 & 14 & 13 & 30 \\
\hline & 20 & $27 \%$ & 1 & 14 & 5 & 20 \\
\hline & 6 & $8 \%$ & 0 & 5 & 1 & 6 \\
\hline & 4 & $5 \%$ & 0 & 0 & 4 & 4 \\
\hline & 75 & $100 \%$ & 4 & 41 & 30 & 75 \\
\hline \multicolumn{7}{|c|}{ 2. Has your degree opened doors for new job opportunities? } \\
\hline & & & Associate's & Bachelor's & Master's & Total \\
\hline \multirow{6}{*}{$\begin{array}{l}5=\text { Strongly Agree } \\
4=\text { Agree } \\
3=\text { Neither } \\
2=\text { Disagree } \\
1=\text { Strongly Disagree } \\
\text { Total }\end{array}$} & 19 & $25 \%$ & 0 & 10 & 9 & 19 \\
\hline & 28 & $37 \%$ & 2 & 19 & 7 & 28 \\
\hline & 20 & $27 \%$ & 1 & 9 & 10 & 20 \\
\hline & 5 & $7 \%$ & 1 & 3 & 1 & 5 \\
\hline & 3 & $4 \%$ & 0 & 0 & 3 & 3 \\
\hline & 75 & $100 \%$ & 4 & 41 & 30 & 75 \\
\hline \multicolumn{7}{|c|}{ 3. Has your degree opened doors for any promotions? } \\
\hline & & & Associate's & Bachelor's & Master's & Total \\
\hline \multirow{6}{*}{$\begin{array}{l}5=\text { Strongly Agree } \\
4=\text { Agree } \\
3=\text { Neither } \\
2=\text { Disagree } \\
1=\text { Strongly Disagree } \\
\text { Total }\end{array}$} & 16 & $21 \%$ & 0 & 8 & 8 & 16 \\
\hline & 29 & $39 \%$ & 3 & 15 & 11 & 29 \\
\hline & 19 & $25 \%$ & 0 & 12 & 7 & 19 \\
\hline & 9 & $12 \%$ & 1 & 6 & 2 & 9 \\
\hline & 2 & $3 \%$ & 0 & 0 & 2 & 2 \\
\hline & 75 & $100 \%$ & 4 & 41 & 30 & 75 \\
\hline \multicolumn{7}{|c|}{ 4. Has your degree enhanced your ability for a specific career field? } \\
\hline \multirow{7}{*}{$\begin{array}{l}5=\text { Strongly Agree } \\
4=\text { Agree } \\
3=\text { Neither } \\
2=\text { Disagree } \\
1=\text { Strongly Disagree } \\
\text { Total }\end{array}$} & & & Associate's & Bachelor's & Master's & Total \\
\hline & 28 & $37 \%$ & 0 & 19 & 9 & 28 \\
\hline & 31 & $41 \%$ & 3 & 13 & 15 & 31 \\
\hline & 12 & $16 \%$ & 1 & 7 & 4 & 12 \\
\hline & 2 & $3 \%$ & 0 & 2 & 0 & 2 \\
\hline & 2 & $3 \%$ & 0 & 0 & 2 & 2 \\
\hline & 75 & $100 \%$ & 4 & 41 & 30 & 75 \\
\hline
\end{tabular}




\section{CONCLUSION}

The aggregate data regarding higher education enrollments and job market shares do not reflect when, where, and why women are pursuing particular collegiate and work opportunities (Maldonado, 2010). According to Waiters (2011), achieving an education has always come at a price for African-American women. Until recently, very few people have had the luxury of acquiring an undergraduate college degree without also working during the day. Much of this was made possible through government grants and financial aid. Waiters (2011) goes on to identify that there is little research, if any, on the perceptions of African-American women concerning what they perceive as sacrifices that they have had to make in achieving their educational and career goals. Waiters acknowledged that in Asia, the education of women is a sensitive issue, yet it is a priority for many Asian nations, according to Hawkins and Su (Waiters, 2011). Women are becoming aware of the value of education and its ability to empower them, yet, in many Asian societies, the education of females falls far below that of males. The gender gap continues to be a major obstacle to a more "balanced educational development strategy."

In his study, Hernandez (1999) concluded that the Hispanic women felt their career objectives had been compromised by external factors relating to their gender and ethnicity brought on by machismo or patriarchal customs. Consequently, cultural expectations and stereotyping Hispanic women as a homogeneous group have further contributed to the career path obstruction of Hispanic women. Hernandez emphasizes the idea that the barriers of traditional roles reinforce the challenges and compromises faced by Hispanic women (Hernandez, as cited in Armijo, 2009). Armijo (2009) found that Latina women statistically remain under-represented in the U.S. workforce, with nearly half of the Latina professionals reporting that their culture challenges hinder their careers (Armijo, 2009).

The responses of this study concluded that over $60 \%$ of female minorities, who obtained a degree from APUS, were obtaining a degree to enhance their abilities in a specific career field and/or to open doors for new job opportunities. In the past, minority women have been faced with many obstacles in order to continue their education and further their careers. Today, there are still obstacles and challenges to overcome, but the rewards are endless. Understanding and managing these challenges will enable minority women to "be all that they can be" in their career field. As John Dewy stated, "Education is a social process. Education is growth. Education is not a preparation for life; education is life itself" (Dewy, 1942).

\section{AUTHOR INFORMATION}

Ana Machuca is a full-time professor in the School of Business and Management. She has been teaching online and face-to-face since 1997 and has been involved in administration, curriculum, and development within Kaplan University. Dr. Machuca's credentials include a Bachelor's Degree in Accounting and Finance from Florida Southern College, a Master's of Accounting and Financial Management (MAFM) from Keller Graduate School, a Master's in Business Administration (MBA) with concentration in Management from Webster University, and a Doctor of Philosophy $(\mathrm{PhD})$ degree in Business Administration with a specialization in Financial Management and Accounting from Northcentral University. She is a Certified Public Accountant (CPA) and a Certified Fraud Examiner (CFE). E-mail: amachuca@kaplan.edu (Corresponding author)

Enid Naranjo is a full-time professor in the School of Business and Management at American Public University System. She has been teaching online since 2009. In her capacity as a Professor, she has taught courses in both English and Spanish, specializing in Business Law and Ethics. She is also skilled in the use and application of ELearning software such as nExt and APUS Sakai. Mrs. Naranjo is a seasoned business professional with experience in multicultural marketing, Hispanic media, non-profit management, and education. She is a graduate of the University of Puerto Rico (B.A.) and Inter American University of Puerto Rico (J.D., 1983). E-mail: olas123@aol.com

Leticia Apolinaris is an adjunct professor in the School of Business at Kaplan University where she has been teaching since 2009. Ms. Apolinaris is also working in different areas of social work with an emphasis on hospital and organization that services family and children. She also worked in the arena of multicultural marketing. Her passion is teaching students in the entrance level in order to create a strong educational foundation as they move 
forward through their educational journey. Leticia Apolinaris is a graduate of Herbert H. Lehman College (BA) and Fordham University (MSW). E-mail: lapolinariss@ Kaplan.edu

Carrie Teresa Maison is an English professor in the College of Arts and Sciences at Northern Virginia Community College. In addition to her position at NVCC, she is also a member of the English faculty at American Public University System (APUS). Maison's credentials include: a Bachelor's degree in English from George Mason University and a Master of Fine Arts in Creative Writing (Poetry) from Queens University of Charlotte. Maison is currently working towards a postgraduate certification in Nonfiction at Queens. She is also a part-time freelance writer for various online publications. E-mail: 98daffodils@ gmail.com

\section{REFERENCES}

1. Armijo, R. J. (2009). The challenges of professional Hispanic women related to personal life, family, education, and profession. Available from ProQuest Dissertations and Theses database. (UMI no. 3366845).

2. Campbell, N. (2011). Hispanic women in leadership: Perceptions of their roads to successful careers. Available from ProQuest Dissertations and Theses database. (UMI no. 3481339).

3. Dewey, J. (1942). Philosopher. University of Chicago.

4. Giddens, A. (1984). The Constitution of society: Outline of the theory of structuration. Berkeley, University of California Press.

5. Maldonado, H. D. (2010). A matter of degrees: Women's higher education decision-making processes related to school, relationships, and work. Available from ProQuest Dissertations and Theses database. (UMI no. 3423495).

6. Offet-Gartner, K. (2008). Sharing the story: Education as the key to unlocking the door of career possibilities with first nations women. Available from ProQuest Dissertations and Theses database. (UMI no. NR44363).

7. U.S. Department of Education, National Center for Education Statistics. (2011). The condition of education 2011 (NCES 2011-033), Indicator 26.

8. U.S. Department of Labor. (2005). Women in the labor force: A data book. Retrieved August 3, 2012 from http://www.dol.gov/wb/factsheets

9. Waiters, L. R. (2011). The perceptions of African American women concerning the intangible cost $(s)$ and/or benefit( $s$ ) of a post-baccalaureate education and career choices. Available from ProQuest Dissertations and Theses database. (UMI no. 3455576). 